\title{
Commercializing a disruptive technology
}

\author{
Simcha Jong \\ Building any biotech business is hard, but building one based on a new, unproven technology or approach \\ requires special care.
}

E ver since its inception in the 1970 s, the

Ebiotech sector has been characterized by technological waves, each of which has spawned successive generations of ventures, and by cycles of boom and bust. Thirty years ago, taking a therapeutic protein developed through recombinant DNA technology all the way from discovery to registration represented a triumph in itself for the biotech industry.

Since that time, most entrepreneurs have been able to build very respectable businesses around a piece of intellectual property (IP) surrounding, for example, a previously unknown class of biological target, and have simply used existing technologies to develop a new chemical or biological entity. But every decade, there have been a few company founders facing the more formidable challenge of commercializing a completely new technology-perhaps a new type of therapeutic modality (for example, monoclonal antibodies, antisense, ribozymes, small interfering RNAs or DNA vaccines) or a new type of service (for example, structure or pathway modeling, or information provision and analysis) - with relatively limited business or scientific precedent on which to base their business.

Although the payoffs for entrepreneurs who are among the first to catch these technology waves have sometimes been enormous, so have the risks. The euphoria surrounding disruptive technologies and the influx of capital that accompanies it is often short lived. For example, as challenges involved in turning new genomics technologies into products became clear after 2000, many firms failed, and the market capitalization of leading genomics firms such as Millennium Pharmaceuticals,

Simcha Jong is a lecturer at the Department of Management Science and Innovation, University College London, Gower Street, London WC1E 6BT, UK.

e-mail:s.jong@ucl.ac.uk
Human Genome Sciences and Incyte dropped more than $85 \%$. More recently, the field of RNA interference (RNAi) has seen a similar disillusionment, with major pharmaceutical companies such as Pfizer and Roche announcing significant cutbacks in the field after a period of heavy investments (Roche alone has dumped more than $\$ 500$ million in RNAi).

In this article, I outline some strategies to increase the chance of success for a business that is first in a new marketplace.

\section{Outlasting the euphoria}

Entrepreneurs in new fields should realize that initial positive investor sentiment probably won't carry their products all the way to the market. Consider that it took more than 20 years for the fundamental monoclonal antibody (mAb) discoveries of the 1970s to lead to US Food and Drug Administration (FDA) approval for blockbuster drugs, such as Avastin (bevacizumab) and Remicade (infliximab), and that each generated sales in excess of $\$ 6$ billion in 2010. So what does it take for entrepreneurs to build business models that will outlast the period of bliss that often arrives with a new disruptive technology?

\section{Box 1 Challenges all around}

Geron (Menlo Park, California) is a good example of a company that has pioneered the commercialization of a nascent technology. Geron's treatment for grade A thoracic spinal cord injuries comprises oligodendrocyte precursor cells differentiated from human embryonic stem cells (hESCs); it is the first such hESC-derived therapy to enter the clinic in the US. As there is no clinical experience in applying hESC-derived cells in the clinic, Geron's managers and scientists have been in mostly uncharted territory while figuring out how to design pilot-scale manufacturing of the cells and gathering the requisite data to support regulatory approval of the approach. Work on manufacturing processes and on formulating benchmarks for safety and efficacy of hESC-derived cells culminated in one of the longest investigational new drug filings in history, counting 21,000 pages. That is hard work for management, and these downstream hurdles can often be bad news for shareholders, too. There were no extended periods during which Geron's shares were trading above their 1996 initial public offering price of $\$ 8$ over the past three years. 
(particularly challenges around resources). Thus, in the absence of downstream partners, entrepreneurs should consider the issues detailed below.

Find the low-hanging fruit. A critical challenge for entrepreneurs following a product strategy is not to be overambitious in setting product goals and to focus on low-hanging fruit. In short, launch applications need to be well articulated and their development path straightforward. Thus, most resources can be allocated to downstream product development. In fact, it's suggested that products should be well advanced beyond the proof-of-concept phase in an academic environment before entrepreneurs take up the technology and seek private funding.

A case in point is ChondroCelect, autologous chondrocytes expanded ex vivo and used in the repair of large cartilage lesions in the knee. ChondroCelect was the first cell-based product to receive market registration from the European Medicines Agency. The product was approved in 2008 and was developed by TiGenix (Leuven, Belgium) around a technique invented more than 20 years ago. As a result, managers were able to use the $€ 29$ million (US $\$ 42$ million) in private funding raised in between TiGenix's formation in 2000 and its initial public offering (IPO) in 2007 (which raised another $€ 46$ million (US\$60 million)) on investments in manufacturing and clinical trials. Advanced BioHealing (Westport, Connecticut), which was acquired by Shire (Dublin, Ireland) in May while it was preparing for an IPO, was founded as a virtual company and followed a similar approach: its product, Dermagraft, had been under development for more than 15 years and was already FDA approved when Advanced BioHealing took it up in 2007.

If managers have difficulties identifying low-hanging fruit, they should look beyond pharmaceuticals to applications for which the development path can be more straightforward and less risky. Although investments in pharmaceutical applications are often associated with a higher upside potential, such applications may be a bridge too far during a new technology's early days. In fact, many early, successful ventures in genetic engineering during the 1980s and genomics during the late 1990s focused on agricultural applications. More recently, new synthetic biology firms such as LS9 (South San Francisco) and Gevo (Englewood, Colorado) are focusing on the market for biofuels for launch applications.

Don't hedge bets. Entrepreneurs are often tempted to pursue multiple product opportunities to spread the risk around. Even so, man- agers of product-oriented firms should realize that because of resource constraints, betting on multiple products is riskier for those developing disruptive technologies. Nicolas L'Heureux is cofounder and CSO at Cytograft (Novato, California), a company working with an autologous, tissue-engineered vascular graft providing hemodialysis access. He explained that the trick to succeeding in disruptive fields is "to be able to stay focused on a single project" until it reaches a level of success in humans before branching out into other products. It is likely that if you use precious cash to pursue multiple opportunities, you end up chasing two hares and catching none.

Look downstream. A problem with focusing on low-hanging fruit, though, is that competitors can often reach for it as well. Moreover, competitors that enter a market later have the advantage of being able to learn from advances (and mistakes) made by first entrants. In the absence of significant resources for upfront investments in differentiating the launch product's basic technology, what other avenues are there for entrepreneurs who are first movers to build a competitive advantage?

These avenues tend to be downstream. As discussed, the basic technology of Advanced BioHealing's launch product had been around for a while before the company took it up, and according to its S-1 filing with the US Securities and Exchange Commission (SEC), two of the company's key patents are set to expire in 2012. Even so, Advanced BioHealing's management looked downstream and realized there was great value in developing marketing capabilities in a new sector, in which there was little awareness about how to value the technologies. Thus, managers focused on creating brand equity and participating in activities geared toward educating patients and doctors about regenerative medicine in general, and about the company's Dermagraft product (polyglycolic acid mesh impregnated with viable, human, neonatal fibroblasts) in particular. Managers expect that the company's more than 150 sales, marketing, reimbursement and policy professionals will outlast the patent protection of the company's launch product as a source of competitive advantage.

Focusing on manufacturing and development capabilities is another option, because new biotech sectors often create unique development and manufacturing challenges that existing firms are not familiar with. That was part of the strategy for NeoStem (New York), which has built a business around banking hematopoietic stem cells that have been mobilized to enter the blood stream by granulocyte colony-stimulating factor. The company's acquisition of Progenitor Cell Therapy (Allendale, New Jersey) in January has positioned NeoStem as a manufacturing and scale-up partner for other companies developing cell-based therapeutics.

Build an 'exploiter' organization. As development paths in new sectors tend to be longer and more complex, with no room to waste resources, the firm's organizational design should be unambiguous. Management scholars often make a distinction between 'exploiter' and 'explorer' organizations, to distinguish between firms that offer an organizational environment conducive to continuous innovation and those that achieve a superior efficiency in performing certain tasks based on pre-existing knowledge ${ }^{1}$.

Entrepreneurs following a product strategy should model their organizations on the exploiter type. In truth, because launch products should be well articulated from the outset anyway, little space for further experimentation and open-ended exploration is needed. Instead, cost containment and development speed should be paramount objectives of organizational design. This means that there is no need for layer upon layer of organization and that it is management's role to set milestones and ensure employees are acutely aware of these. Moreover, there is a danger for product-oriented firms to waste resources on overqualified employees. Because skills needed in these firms are generally product specific, training can be mostly in-house, and there often is no urgent need for the broad, generic skill set brought in by staff with more advanced degrees. Reflecting on the danger for productoriented firms becoming too unwieldy early on, Cytograft's L'Heureux says, “There tends to be too many $\mathrm{PhDs}$; too many generals, not enough soldiers, as they like to say. We've made a commitment early on that there would be a lot of soldiers, and while the generals would be overworked, and work 80 hours per week and not sleep enough, I think it makes sense at the beginning to have that proportion, and not have eight PhDs and two technicians."

\section{The platform strategy}

Given the challenges in finding downstream partners in new markets, entrepreneurs seeking to commercialize disruptive technologies should make exploring partnering opportunities in established markets a priority both to validate the firm's technology platform and create early exit opportunities for investors. I explore some of the various options below.

Serve existing markets. Instead of trying to realize the full potential of disruptive tech- 
nologies by creating a new market, the trick for entrepreneurs seeking to commercialize a platform is to focus on application areas in an existing market in which incumbent firms already have a strong position and can leverage existing downstream capabilities.

Managers at Genentech (South San Francisco), which is owned by Roche (Basel, Switzerland), were the first to successfully use this approach to validate the firm's platform during the late 1970s and early 1980s. Genentech's insulin product Humulin, the first genetically engineered product to reach the clinic, in 1982, was teamed with Eli Lilly (Indianapolis), which was a dominant firm in the insulin market. Thus, Genentech was able to benefit from Eli Lilly's regulatory experience and marketing capabilities with Humulin's commercialization.

A more recent example, from the market for induced pluripotent stem (iPS) cell technologies, is iPierian (South San Francisco). iPierian aims to use its platform to develop therapies in-house, including cell-based ones for neurodegenerative disorders such as Parkinson's disease, spinal muscular atrophy and amyotrophic lateral sclerosis. Even so, iPierian's short- to medium-term goal is to use its platform in the development of more conventional small molecule and protein drugs in markets already served well by pharmaceutical companies. These markets include those for cardiovascular and metabolic diseases, for which iPierian can rely on the downstream capabilities of pharmaceutical partners.

Capitalize on unique opportunities with IP. For entrepreneurs following a platform strategy in new sectors, it is crucial to not only seek patent protection but also create a tight network of researchers who hold critical tacit knowledge concerning the firm's platform. An effective way to do this is to bring in academic thought leaders as members of the scientific advisory board or as consultants. This not only gains the firm access to important technical expertise but also allows it to turn these thought leaders from potential competitors into stakeholders.

There are also two unique challenges that entrepreneurs need to face to increase the longterm value of their disruptive platforms that are not open to entrepreneurs in established sectors. The first challenge is to, in effect, create a so-called commercial lock on the key technologies underlying the new sector. Although the IP estate is still up for grabs in new sectors, as biotech sectors mature, the value of the IP estate fragments, and it becomes very difficult for a single firm to capture a significant share of the estate's value. The field of antibodies is a good example, as there was no firm that early on laid claim on the key pieces of IP estate, which ended up highly fragmented. Creating a lock on technology development in new sectors entails securing what are known as blocking patents. To this end, a platform firm's business plan should discuss the techniques and processes the founders see as central to their technological field's development, as well as who are the current IP holders in the field. For each of these IP holders, entrepreneurs should explain how they will deal with the threat represented and how it will be mitigated (Box 2).

IP consolidation strategies centered on the creation and exploitation of blocking patents often attract controversy, especially when firms impose licensing policies that are perceived as overly restrictive, similar to the policies used by Genetic Technologies (Fitzroy, Australia) to license its 'junk patents'. An unwillingness to disclose critical knowledge regarding a firm's IP estate is also seen as hindering $R \& D$ progress, highlighted in a recent case study of Sangamo BioSciences (Richmond, California) and its IP estate related to the engineering and use of zinc-finger proteins ${ }^{3}$. A key challenge for entrepreneurs in a new field is to establish the viability of the field and mobilize a wide range of academic and commercial actors behind it. Therefore, in formulating IP licensing and disclosure policies, it is pertinent to pay attention to balancing the short-term need for licensing income as well as the long-term need to attract a wide range of academic and commercial partners as participants in a new marketplace.

A second challenge is that early on, the IP landscape of a new sector is highly uncertain because outcomes of patent decisions and litigation are still unknown. Therefore, it is important to hedge one's bets and file not only for blocking patents on critical technologies but also for patents on the application of these technologies. For example, this approach has been crucial to the IP strategies of firms seeking to secure strong positions around expressed sequence tags ${ }^{4}$. Reflecting on challenges in the iPS cell field, John Walker, who held senior positions at several stem cell firms, including that of CEO at iPierian, notes, "Because the IP landscape is ill defined at this point, for building a company, it is critical to base your competitive advantage on your ability to execute. What's important is to apply the technology to a specific area and application and to become an expert in that and to develop a lot of IP around the application of the technology."

Build an explorer organization. The capability to 'source in' external knowledge from the scientific knowledge frontier tends to be more important for platform firms in new sectors. Such a capability requires long-term investments in laboratories and scientific partnerships as well as a distinctive organizational design. In fact, this design should be diametrically opposed to the design of the exploiter organizations of product firms and more akin to the design of what management scholars typify as explorer organizations. Such organizations build in space for open-ended activities or what management scholars refer to as 'slack' ${ }^{5}$. In this respect, in organizing the firm's basic R\&D during its early days, Genentech set an example for platform firms in new sectors. Genentech went to great lengths to allow researchers to pursue opportunities that might pop up in unexpected places or might have no immediate value. Venture capitalists are often quite hesitant to support the elaborate kind of basic R\&D infrastructure that is associated with the Genentech model. However, incorporating a few of the elements of this model, such as allowing employees to work on personal pet projects one day per week and encouraging them to publish in journals, will get you a long way in ensuring your firm stays in tune with the latest research and is better able to capitalize on new scientific developments as they arise.

Also, managers should think about how to attract top graduates from leading universities. The scientific advisory board forms an excellent source for referrals for scientific talent, in particular during the firm's early

\section{Box 2 New frontiers}

Alnylam Pharmaceuticals (Cambridge, Massachusetts) was founded in 2003 during the early days of research on RNA interference (RNAi) by some of the field's pioneers. Although RNAi was in its infancy then, the founders recognized a unique opportunity to secure key pieces of intellectual property (IP) estate in the field early on. As the company's CEO John Maraganore puts it, "The reason we did the IP consolidation strategically was to avoid the fragmentation of value that occurred in the settings of other big platform technologies....Between June of 2002 and roughly the end of 2003 , in a dogged, persistent, calculated fashion, we literally had a roadmap of all the key inventions in the field, who the inventors were, what were the academic institutions where the licenses were being held, and we negotiated all these different license grants - license agreements - with universities. In one case, we acquired a company in July 2003, Ribopharma, because they had some critical patents" 6 . 
growth. In addition, to increase the company's visibility among potential employees, it is important to hire at least one highflier in the firm's scientific niche early on.

\section{Concluding remarks}

Capitalizing on radically new technologies that require major alterations to the way business is conducted across the different stages of the life sciences value chain imposes daunting challenges on entrepreneurs. However, being prepared for these challenges, and examining proposed business models, should help entrepreneurs a long way toward overcoming them.

\section{ACKNOWLEDGEMENTS}

This work was supported by the Innovation Research Initiative, which is funded by BIS, ESRC, NESTA and TSB (ESRC reference: RES-598-25-0032).
1. March, J.G. Organ. Sci. 2, 71-87 (1991).

2. Dennis, C. Nature 423, 105 (2003).

3. Chandrasekharan, S. et al. Nat. Biotechnol. 27, 140144 (2009).

4. Simon, B.M. \& Scott, C.T. Nat. Biotechnol. 29, 229230 (2011)

5. Cyert, R.M. \& March, J. A Behavioral Theory Of The Firm. (Prentice-Hall, Englewood Cliffs, New Jersey, 1963).

6. Shih, W. \& Chai, S. Alnylam Pharmaceuticals: Building Value From The IP Estate. Case 9-611-009 (Harvard Business School Publishing, Boston, 2010). 